\title{
When ecological marginality is not geographically peripheral: Exploring genetic predictions of the centre-periphery hypothesis in the endemic plant Lilium pomponium
}

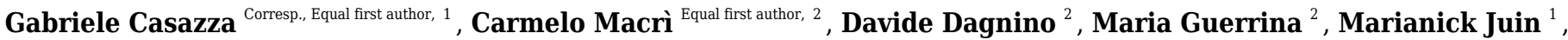 \\ Luigi Minuto $^{2}$, John D. Thompson ${ }^{3}$, Alex Baumel ${ }^{1}$, Frederic Medail ${ }^{1}$ \\ ${ }^{1}$ Institut Méditerranéen de Biodiversité et d'Ecologie marine et continentale (IMBE), Aix Marseille Université, Avignon Université, CNRS, IRD. Technopôle \\ de l'Arbois-Méditerranée, Aix en Provence, France \\ 2 Department for the Earth, Environment and Life Sciences (DISTAV), University of Genoa, Genova, Italy \\ 3 Centre d'Ecologie Fonctionnelle et Evolutive, CNRS, Montpellier, France \\ Corresponding Author: Gabriele Casazza \\ Email address: gabriele.casazzabot@gmail.com
}

Background. Quantifying variation of genetic traits over the geographical range of species is crucial for understanding the factors driving their range dynamics. The centre-periphery hypothesis postulates, and many studies support, the idea that genetic diversity decreases and genetic differentiation increases toward the geographical periphery due to population isolation. The effects of environmental marginality on genetic variation has however received much less attention.

Methods. We tested the concordance between geographical and environmental gradients and the genetic predictions of centre-periphery hypothesis for endemic Lilium pomponium in the southern Alps.

Results. We found little evidence for concordance between genetic variation and both geographical and environmental gradients. Although the prediction of increased differentiation at range limits is met, genetic diversity does not decrease towards the geographical periphery. Increased differentiation among peripheral populations, that are not ecologically marginal, may be explained by a decrease in habitat availability that reduces population connectivity. In contrast, a decrease of genetic diversity along environmental but not geographical gradients may be due to the presence of low quality habitats in the different parts of the range of a species that reduce effective population size or increase environmental constraints. As a result, environmental factors may affect population dynamics irrespective of distance from the geographical centre of the range. In such situations of discordance between geographical and environmental gradients, the predictions of decreasing genetic diversity and increasing differentiation toward the geographical periphery may not be respected. 


\section{When ecological marginality is not geographically}

2 peripheral: exploring genetic predictions of the

3 Centre-Periphery Hypothesis in the endemic plant

4 Lilium pomponium

6 Gabriele Casazza ${ }^{1}$ Carmelo Macrí $^{2}$, Davide Dagnino ${ }^{2}$, Maria Guerrina ${ }^{2}$, Marianick Juin ${ }^{1}$, Luigi

7 Minuto $^{2}$, John D. Thompson ${ }^{3}$, Alex Baumel ${ }^{1}$, Frédéric Médail ${ }^{1}$

8

$9{ }^{1}$ Institut Méditerranéen de Biodiversité et d'Ecologie marine et continentale (IMBE), Aix

10 Marseille Université, Avignon Université, CNRS, IRD. Technopôle de l'Arbois-Méditerranée,

11 BP 80, 13545 Aix-en-Provence cedex 4, France

$12{ }^{2}$ Department for the Earth, Environment and Life Sciences (DISTAV), University of Genoa,

13 Corso Europa 26, 16132 Genoa, Italy

$14{ }^{3}$ CEFE, Univ Montpellier, CNRS, EPHE, IRD, Univ Paul Valéry Montpellier 3, Montpellier, 15 France, France

17 Corresponding Author:

18 Gabriele Casazza $^{1}$

19 Aix Marseille Université, Avignon Université, CNRS, IRD, IMBE. Technopôle de l'Arbois-

20 Méditerranée, BP 80, 13545 Aix-en-Provence cedex 4, France

21 Email address: gabriele.casazza@unige.it 


\section{Abstract}

24 Background. Quantifying variation of genetic traits over the geographical range of species is crucial for 25 understanding the factors driving their range dynamics. The centre-periphery hypothesis postulates, and 26 many studies support, the idea that genetic diversity decreases and genetic differentiation increases 27 toward the geographical periphery due to population isolation. The effects of environmental marginality 28 on genetic variation has however received much less attention.

Methods. We tested the concordance between geographical and environmental gradients and the genetic predictions of centre-periphery hypothesis for endemic Lilium pomponium in the southern Alps.

Results. We found little evidence for concordance between genetic variation and both geographical and environmental gradients. Although the prediction of increased differentiation at range limits is met, genetic diversity does not decrease towards the geographical periphery. Increased differentiation among peripheral populations, that are not ecologically marginal, may be explained by a decrease in habitat availability that reduces population connectivity. In contrast, a decrease of genetic diversity along environmental but not geographical gradients may be due to the presence of low quality habitats in the different parts of the range of a species that reduce effective population size or increase environmental constraints. As a result, environmental factors may affect population dynamics irrespective of distance environmental gradients, the predictions of decreasing genetic diversity and increasing differentiation toward the geographical periphery may not be respected.

\section{Introduction}

46 Quantifying variation of genetic traits over the geographical range of species is crucial for

47 understanding the factors driving their range dynamics and in particular the ecological and 
48 evolutionary processes that act on populations on the periphery of a species range (Thomas et al., 49 2001). As climate change begins to induce diverse effects on plant and animal populations

50 (Thomas et al., 2004; Parmesan, 2006; Thompson, 2020) understanding the processes that drive 51 variation in traits across the species' range is of crucial importance.

52 A major theory that has been developed to enhance our understanding of traits and genetic 53 variation among-population across the species range is the Centre-Periphery Hypothesis 54 (hereafter $\mathrm{CPH}$ ). The CPH postulates that species' abundance and performance decrease from 55 the geographical centre of the range toward the periphery due to the deterioration of 56 environmental conditions (Hengeveld \& Haeck, 1982; Brown, 1984; Sagarin \& Gaines, 2002;

57 Gaston, 2003; Pironon et al., 2015; Pironon et al., 2017). A prediction of the CPH is that 58 population genetic diversity is highest in the geographical centre of the range and decreases 59 toward the periphery where higher genetic differentiation is predicted as a result of population 60 isolation (Eckert et al., 2008; Pironon et al., 2017). Geographically peripheral populations are 61 also expected to exhibit lower genetic diversity because in such situation they may occur in 62 environmentally marginal habitats (Eckert et al., 2008). Indeed, demographic processes due to 63 harsh or atypical environmental conditions at the geographical periphery of a species' range can 64 lead to low effective population size that leads to increased inbreeding and low genetic diversity 65 (Griffin et al., 20014). Moreover, a reduction in genetic diversity may occur in small peripheral 66 populations that experience strong selection and weak migration (Schoville et al., 2012). In fact, 67 the CPH often assumes (but see Pironon, Papuga et al. 2017) that geographically peripheral 68 populations are also environmentallu marginal and postulates that a decrease in genetic diversity 69 and an increase in genetic differentiation towards the periphery is due to poor demography, small 
70 population size and low density. Peripheral populations may thus be more prone to extinction

71 (Brown et al., 1996; Gaston, 2004).

72 However, a concordance between "geographical periphery" and "environmental marginality"

73 (Brown, 1984) might not always be correct (Soulé, 1973; Pironon et al., 2017). In fact,

74 geographically peripheral populations may occur in conditions similar to those in the centre of

75 the range (Piñeiro et al., 2007; Kropf et al., 2008) or in different, but not marginal,

76 environmental conditions (Papuga et al., 2018). Moreover, variation in ecological factors may

77 impose harsh environmental marginal conditions in any part of the species' range (Soulé, 1973).

78 Peripherally isolated populations may also act as source of adaptative diversity under climate

79 change (Macdonald et al., 2017; El Mousadik \& Petit, 1996a; El Mousadik \& Petit, 1996b;

80 Thompson, 2020).

81 Finally, when different factors are examined (e.g., demographic rates, population size and

82 populations density), they seldom all follow CPH predictions (Pironon et al., 2017). This

83 inconsistence is probably because of the complexity of spatial, ecological, and/or historical

84 factors across a geographical gradient (Eckert et al., 2008; Pironon et al., 2015). As a result,

85 although not all expectations are met, some predictions are often supported and the relative

86 importance of the relationships among these factors may be dramatically different from one

87 species to another, resulting in a lack of support for some $\mathrm{CPH}$ predictions, even those

88 concerning reduced genetic variation within-population and enhanced differentiation among-

89 populations that are among the most commonly observed trends (Lira-Noriega \& Manthey,

90 2014; Pironon et al., 2017; Kennedy et al., 2020). Several studies suggest that environmental

91 gradients may be more important than geographical gradients for the expression of trends in

92 genetic diversity (Pilot et al., 2006; Cimmaruta et al., 2005; Lira-Noriega \& Manthey, 2014). 
93 This may be due to the fact that populations are less spatially abundant and smaller in marginal

94 environments than near the environmental optimum. This pattern may be particularly important

95 in shaping the spatial distribution of genetic variation in species growing in areas that have

96 remained stable over time (Nunes et al., 2017), e.g. in climate refugia (Hewitt, 1999; Gavin et al.,

97 2014; Hampe \& Petit, 2005), regardless of their current size or density. Unfortunately, very few

98 studies have been conducted on species historical ranges in relation to climate change (but see

99 Pouget et al., 2013; Kennedy et al., 2020).

100 Lilium pomponium L. provides an ideal species to test the $\mathrm{CPH}$ predictions for genetic variation

101 along geographical and ecological gradients. This plant species has a geographical distribution

102 that is endemic to the Maritime and Ligurian Alps where it occurs along a wide altitudinal

103 gradient. In the study area, a heterogeneous impact of glaciations and topographic complexity

104 probably minimized population extinction during Quaternary glaciations (Diadema et al., 2005;

105 Casazza et al., 2008, Casazza et al., 2016). Because of the high topographical complexity of the

106 area and the potentially low impact of the glaciation on the distribution range of the species, we

107 expect a low concordance between the geographical and environmental gradient but a close

108 relationship between the genetic variation and environmental gradient. To test these

109 expectations, we addressed the following questions. First, are geographical and environmental

110 centre-periphery gradients correlated? Second, are genetic differentiation and genetic diversity

111 associated with geographical and environmental gradients or is there discordance in relationships

112 with those types of gradient?

114 Materials \& Methods

115 Study species, data collection and sampling 
116 Lilium pomponium L. (Liliaceae) is a perennial herb (geophyte) endemic to the Maritime and

117 Ligurian Alps - a region that represents a major regional hotspot of endemism and plant

118 diversity in the Mediterranean Basin (Thompson 2020). It grows in rocky grassland and

119 shrubland from 100 to 2,000 m of altitude in an area of roughly $7.000 \mathrm{~km}^{2}$ (Noble \& Diadema,

120 2011). The species has a self-incompatible outcrossing breeding system, with a poor capacity for

121 selfing (Casazza et al., 2018). Species occurrences were obtained from field surveys and the

122 Conservatoire Botanique National Méditerranéen SILENE data base

123 (http://www.silene.eu/index.php?cont=accueil) and LiBiOss (Regione Liguria;

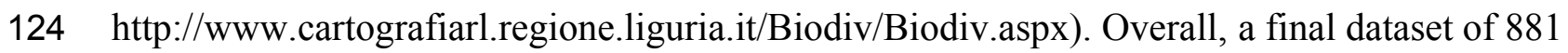

125 occurrence records was used to assess the global distribution of the species and to determine

126 central and peripheral sites and those that may be environmentally marginal. A total of 197

127 individuals were sampled from 20 populations that cover the entire geographical and altitudinal

128 range of the species (Fig. $1 \mathrm{~A}$ and Table 1). Field collection was authorized by the Conservatoire

129 Botanique National Méditerranéen de Porquerolles and the Regione Liguria (Decree n. 859 of

$130 \quad 22 / 08 / 2018)$

131

132

DNA extraction and genotyping

133 Genomic DNA was isolated from fresh leaves according to Kobayashi et al. (1998). Frozen

134 leaves samples were ground in a mixer 150 mill “TissueLyser” (Quiagen-Retsch). Total DNA

135 was extracted using NucleoSpin Plant II 151 Kit (Macherey \& Nagel, Germany). DNA

136 concentrations were measured using a photometer (Biophotometer, Eppendorf, Germany). The

137 AFLP method was performed as describe by Vos et al. (1995) using laboratory equipment

138 previously employed by Vidaller (2018).

Peer] reviewing PDF | (2020:05:48726:2:0:NEW 19 Jan 2021) 
139 AFLP genotyping was based on the protocol described by Vos et al. (1995). $100 \mathrm{ng}$ of DNA

140 were digested using the restriction enzymes Eco RI and Tru 9I (Fisher Scientific, France) for $3 \mathrm{~h}$

141 at $37^{\circ} \mathrm{C}$ and then for $3 \mathrm{~h}$ at $65^{\circ} \mathrm{C}$ in a total volume of $25 \mu \mathrm{l}(15 \mu \mathrm{L}+10 \mu \mathrm{l}$ of DNA). Digestion

142 products were ligated to $0.5 \mu \mathrm{L}$ Eco and $25 \mu \mathrm{L}$ Mse adaptors for $3 \mathrm{~h}$ at $37^{\circ} \mathrm{C}$ and treated with $\mathrm{T} 4$

143 DNA Ligase and $0.1 \mu \mathrm{L}$ of $100 \mathrm{mM}$ ATP to a final volume of $25 \mu \mathrm{L}(5 \mu \mathrm{L}+20 \mu \mathrm{l}$ of restriction

144 products). Ligation products were diluted eight times and pre-selective PCR amplification was

145 performed using EcoR $1+\mathrm{A}$, Mse $+\mathrm{C}$ primers and Taq DNA polymerase in a $44.5 \mu \mathrm{L}$ volume. The

146 profile of pre-amplification thermocycle was $94^{\circ} \mathrm{C}$ for $2 \mathrm{~min}$, followed by 20 cycles at $94^{\circ} \mathrm{C}$ for

$14745 \mathrm{~s}, 56^{\circ} \mathrm{C}$ for $45 \mathrm{~s}, 72^{\circ} \mathrm{C}$ for $1 \mathrm{~min}$ and $72^{\circ} \mathrm{C}$ for $10 \mathrm{~min}$. For the selective amplification, three

148 primer combinations were chosen for PCR: ASII: EcoR1-AGG/ MseI -CGG, ASIII: EcoR1-

149 AGC/ MseI -CAG, ASVII: EcoR1-AGC/ MseI -CTG dyed with 6-FAM fluorescence at 5' Eco

150 end (Eurofins Genomics, Ebersberg, Germany).

151 One Hundred times diluted pre-amplification products were used to perform selective

152 amplification in a final volume of $20 \mu \mathrm{L}(15 \mu \mathrm{L}+5 \mu \mathrm{L}$ of diluted pre-amplification products).

153 For the selective amplification thermocycle we used $94^{\circ} \mathrm{C}$ for $2 \mathrm{~min}, 10$ cycles of $94^{\circ} \mathrm{C}$ for $30 \mathrm{~s}$,

$15465^{\circ} \mathrm{C}$ for $30 \mathrm{~s}$ (step $-1^{\circ} \mathrm{C}$ per cycle), $72^{\circ} \mathrm{C}$ for $1 \mathrm{~min}$, followed by 22 cycles at $94^{\circ} \mathrm{C}$ for $30 \mathrm{~s}, 56^{\circ} \mathrm{C}$

155 for $30 \mathrm{~s}, 72^{\circ} \mathrm{C}$ for $1 \mathrm{~min}, 72^{\circ} \mathrm{C}$ for $5 \mathrm{~min}$ and $4{ }^{\circ} \mathrm{C}$ for $2 \mathrm{~h}$. The fragment length produced by the

156 amplification was separated and quantified by electrophoresis using an ABI 3730xl DNA

157 analyser (Applied Biosystems, Foster City, California, U.S.A.) with GS600 LIZ size marker.

158 Peaks were scored in Peak Scanner V 1.0 (Applied Biosystems) as present (1), absent (0), or "no

159 data" (NA). We utilised Raw Geno 2.0 (Arrigo et al., 2009) to select the fragments longer than

$160100 \mathrm{bp}$ and smaller than $200 \mathrm{bp}$. Maximum binning between peaks was set at 1.75 and minimum 
161 at 1.5. The error rate was calculated as mismatches ratio over matches in 32 replicated

162 individuals (Bonin et al., 2004).

163

164 Estimation of geographical and environmental centre-periphery gradient

165 We used different measures to describe the geographical and environmental centre-periphery

166 gradients. To identify geographically central and peripheral populations we calculated the 167 geographical centre of distribution by averaging the coordinates of the occurrences and the

168 distributional limits by calculating the minimum convex hull polygon that included all the known 169 occurrences of L. pomponium. Following this, geographical peripheral populations were 170 identified by calculating for each occurrence its distance from the geographical centre, its 171 shortest distance to the edge of the convex hull and the ratio between these two distance 172 measures.

173 To assess environmental marginality nineteen bioclimatic variables representative of the 174 period 1979-2013 were downloaded from the Chelsa climate database website (Karger et al., 175 2017a; Karger et al., 2017b; www.chelsa-climate.org) at 30-s (c. $1 \mathrm{~km})$ spatial resolution. We 176 extracted values of bioclimatic variables from cells where the species occurs and defined the 177 climatic space occupied by the species on the basis of the first two axes of a principal component 178 analysis (PCA) using all cell values. Environmental marginality was assessed by calculating the 179 Euclidean distance from the centroid of the climatic space and the Mahalanobis distance from the 180 mean of the climatic space.

181

182 Data analysis 
183 Genetic diversity was measured for each population by calculating Nei’s diversity index (h) and

184 Shannon's information index (I) using POPGENE v. 1.32 (Yeh et al., 1997). Because the various

185 measures of population differentiation quantify different aspects of population structure, we

186 estimated genetic differentiation among populations by using three different measures: the

187 fixation index $\mathrm{F}_{\mathrm{ST}}$, estimated by using ARLEQUIN 3.11 (Excoffier et al., 1992) and Rho

188 (Ronfort et al., 1998) and Jost's D (Jost, 2008) pairwise distance matrix using GenoDive 3.0

189 (Meirmans, 2020). To estimate the genetic differentiation among-population, we calculated the

190 average of pairwise $\mathrm{F}_{\mathrm{ST}}$, Rho and $\mathrm{D}$ values for each population with all other populations. We

191 calculated Pearson product moment correlations between geographical and environmental

192 centre-periphery distance measures and between genetic parameters and the centre-periphery

193 distance measures.

194

195 Results

196 Geographical and environmental gradients

197 The first two axes of PCA of climatic data explained $79.71 \%$ of the overall climatic variance

198 (29.03\% and 50.68\%, respectively in Fig. S1). The first PCA axis is positively related to

199 temperature-related parameters and negatively related to precipitation during the warm and dry

200 season. The second axis is positively related to precipitation during the wet and cool seasons and

201 negatively related to temperature seasonality indices. Sites that are marginal in climatic space

202 occurred throughout the entire distributional range, as witnessed by the occurrence of sites that

203 are far from the climatic centroid both near the geographical centre and in northern and southern

204 geographically peripheral sites (dark red areas in Fig. 1C and E and Table 1). 
205 The distance from the geographical centre was higher in eastern and western peripheral sites than 206 in northern and southern peripheral sites (dark red areas in Fig. 1B). As a result, sites farthest

207 from the distributional edges occurred in a long and thin belt close to the centre of distributional 208 range (dark red areas in Fig. 1D). Likewise, areas with a low ratio between distance from the 209 edge and the centre of distribution occurred mainly at the eastern and western geographical 210 periphery (light red areas in Fig. 1F). In line with these results, the distance from the climatic 211 centroid was not correlated $(\mathrm{r}=0.09$ and $\mathrm{r}=0.05$ according to Euclidean and Mahalanobis 212 distance, respectively) with distance from the geographical centre (Fig. 1 and 2A and D and 213 Table 1) and was only poorly negatively correlated with distance from distributional edge and 214 the edge/centre distance ratio (Fig. 1 and 2B,C,E and F and Table 1).

216 Genetic diversity

217 The three AFLP primer pairs produced 134 polymorphic fragments for 197 individuals (Table 2). 218 The AFLP error rate based on 32 replicates was $2.02 \%$. Genetic diversity indices per population 219 ranged from 0.11 to 0.30 with a mean of $0.22( \pm 0.04)$ and from 0.19 to 0.43 with a mean of 0.34 $220( \pm 0.06)$ according to Nei’s diversity index and Shannon information index, respectively (Table 2213 ). Average $F_{\mathrm{ST}}$ between each population and all remaining populations ranged from 0.034 to 2220.152 , the average Jost's D ranged from 0.032 to 0.108 and the average Rho ranged from 0.008 223 to 0.321 (Table 3). Populations with low and high genetic diversity were scattered throughout the 224 distributional range (Fig. 3A and B). In particular, populations with lowest values occurred near 225 the geographical centre (i.e., P05), as well as near both the southern (i.e., P01) and the northern 226 (i.e., P20) periphery of the distribution. Similarly, populations with high values occurred both 227 near the geographical centre (i.e., P07 and P11) and near the periphery (i.e., P14 and P16). 
228 Populations with low and high $\mathrm{F}_{\mathrm{ST}}$ and Jost's D values were scattered throughout the 229 distributional range (Fig. 3C and D). In contrast, populations with high Rho values occurred 230 mainly near the geographical periphery (i.e., P01, P13, P16 and P17 in Fig. 3E) while 231 populations with low Rho values occurred near the geographical centre (i.e., P04, P06 and P07). 232 In line with this pattern, intra-population genetic diversity was not significantly correlated with 233 geographical distance measures (Table 4). Two measures of average inter-population 234 differentiation (i.e., $\mathrm{F}_{\mathrm{ST}}$ and Jost's D) were not correlated with measures of geographical 235 marginality while Rho index was significantly correlated with measures of geographical

236 237 238 239 240

\section{1}

242 243 244 245 246 247 248 249 250 marginality, increasing toward the geographical periphery (Table 5). Genetic diversity indices

were significantly correlated with both distances from climatic centroid (Table 4) while none of the genetic differentiation indices per population were significantly correlated with environmental distances (Table 5).

\section{Discussion}

In this study on Lilium pomponium, the central-periphery hypothesis $(\mathrm{CPH})$ assumptions of concordance between geographical and environmental gradients are not supported neither is the prediction of decreasing genetic diversity towards the geographical periphery. Our results nevertheless provide support for the prediction of increasing differentiation towards the range periphery.

\section{Lack of concordance among geographical and environmental gradients}

249 An implicit assumption of the $\mathrm{CPH}$ is a symmetrical, monotonic deterioration of environmental condition from the centre of the distribution toward the periphery (Brown, 1984). However, in 
251 mountainous environments, such as the Maritime and Ligurian Alps where L. pomponium

252 occurs, environmental factors change over very short distances because of high topographic

253 complexity (Körner, 2003; Casazza et al., 2008; Thompson, 2020), imposing environmentally

254 marginal conditions in scattered and diffuse parts of a given species' range. Moreover,

255 topographic heterogeneity may decouple site climatic conditions from regional climatic values,

256 reducing our capacity to detect causal factors related to demographic process and environmental

257 variation (Hannah et al., 2014; Patsiou et al., 2014).

258 In L. pomponium climatically marginal conditions were found both at the periphery of

259 distribution and close to the geographical centre, mainly on valley floors (dark red areas in Fig. 1

$260 \mathrm{C}$ and $\mathrm{E}$ and Table 1). This scattered distribution of central and marginal environmental

261 conditions in different parts of the distributional range of this species are probably favored by the

262 succession of high and low elevation areas. In fact, in the study region, tectonic, glacial and

263 fluvial processes have shaped the deeply incised valleys that are characteristic of the southern

264 Alps (Sanchez et al., 2010). As a result, the lack of correlation between geographical and

265 environmental distances is not surprising (Fig. 2).

266 In addition, the distribution range of L. pomponium is largely west-east orientated because the

267 north-south extension is constrained by the sharp altitudinal gradient of the mountain chain. As a

268 result, the east and west peripheral populations are further away from the centre than south and

269 north peripheral populations (Fig. 1B-F). For this reason, harsh conditions in the latter are closer

270 to the geographical centre than harsh conditions in the former peripheral populations (dark red

271 areas in Fig. $1 \mathrm{C}$ and E). This asymmetry may explain why correlations are higher between

272 environmental gradients and distance from the edge of distribution than between environmental

273 gradients and the distance from the geographical centre (Fig. 2 B, D and F). In L. pomponium, 
274 the weak association between geographical and environmental distances is thus closely affected

275 by the complex topography of the region that causes a discrete and strongly asymmetrical

276 distribution of environmental conditions across the distributional range. Correlations between

277 geographical and ecological gradients thus may not occur in areas of high localized spatial

278 heterogeneity. Indeed, the occurrence of central environmental conditions at the geographical

279 margins (white areas in Fig. 1C and E) suggests that in L. pomponium range limits may be due to 280 other factors, such as a gradient in habitat availability, rather than a gradient in habitat quality.

281 This supports the idea that local environmental conditions (such as in microrefugia) explain the 282 occurrence of a patchy distribution (Patsiou et al., 2014).

283

\section{Genetic structure and the $\mathrm{CPH}$}

285 In general, intra-population genetic diversity is expected to be associated with inter-population 286 differentiation because stochastic genetic drift due to change in population size causes both a 287 decline in genetic diversity within populations and divergence among populations (Eckert et al., 288 2008). In fact, peripheral populations having a low genetic diversity usually have also a high 289 genetic differentiation (Pironon et al., 2017). However, our results do not provide support for the $290 \mathrm{CPH}$ prediction of a reduction in within-population genetic diversity towards the periphery but 291 do provide evidence for an increase in inter-population genetic differentiation in peripheral 292 populations relative to those in the center.

293 For L. pomponium, although Rho measure of genetic differentiation illustrate high genetic 294 differentiation near the geographical periphery, suggesting a decrease in gene flow among 295 peripheral populations, we found no evidence for a decline in genetic diversity in peripheral 296 populations (Fig. 3 and Table 3 and 4). The difference between Rho and both $F_{S}$ T and Jost's D is 
297 probably because of Rho is independent from the selfing rate, while the other measures increase 298 when self-fertilization occurs within populations (Ronfort et al., 1998). This may explain why 299 some small-sized populations near the geographical centre but far from environmental centre 300 (i.e., P04, P05 and P08 in Table 3) have high $\mathrm{F}_{\mathrm{ST}}$ and Jost'D values and low Rho values. In fact, 301 the high number of flowers per inflorescence detected in these small populations may favour 302 geitonogamous pollination among flowers on the same plant (Macrì et al. 2021). In small sized 303 populations of facultative-autogamous species, like L. pomponium (Casazza et al. 2018), 304 geitonogamy may assure the production of a small, but regular number of seeds (Roberts et al. 305 2014), but at the cost in terms of reduced outcrossing (Lloyd 1992; Harder \& Barrett 1995). 306 The high genetic differentiation among peripheral populations suggested by Rho index may be 307 the result of a decrease in the availability of suitable habitat and therefore a more (naturally) 308 fragmented distribution of populations rather than the result of a decline in habitat quality and 309 population size (Pironon et al., 2017). In fact, the reduction in density of suitable habitat may 310 reduce population connectivity both by pollen and seeds (Hargreaves \& Eckert, 2014; Young et 311 al., 1996), favouring isolation of populations and resulting in higher inter-population 312 differentiation. Moreover, in L. pomponium population connectivity may be further reduced by a 313 decrease in suitable habitat due to (i) shrubland or forest expansion in mid-elevation of high 314 elevation sites (Carlson et al., 2014) and/or (ii) urbanization in peripheral coastal lowland areas 315 (Noble \& Diadema, 2011). Given that gene flow in perennial plants mainly occurs by pollen 316 transfer (Levin \& Kerster, 1974; Ennos, 1994 Tarayre et al., 1997), pollen limitation detected in 317 the southernmost populations of $L$. pomponium may further drive the genetic differentiation 318 among these populations (Macrì et al. 2021). 
of environmental conditions (Eckert et al., 2008; Pironon et al., 2017). However, in L.

321 pomponium genetic diversity does not decrease with the distance from the geographical centre

322 but does decline with distance from climatic centroid (Table 4). The lack of association between

323 genetic diversity and distance from the geographical periphery is indicative of historical range

324 stability, and of the existence of patchwork of many local refugia, the so-called refugia within

325 refugia hypothesis. The occurrence of widespread local refugia characterizes the Mediterranean

326 region, explaining the persistence of species during the Pleistocene glaciation cycles (Médail \&

327 Diadema, 2009; Thompson, 2020) and their ability to rapidly recolonize new locations at higher

328 altitude or latitude at the end of glaciation (Villellas et al., 2014; Ferreira et al., 2015).

329 In species survived in few glacial refugia, patterns of genetic variation have been strongly shaped

330 by past climate-driven range dynamics, and consequently a decrease of within-population genetic

331 diversity is expected towards recently colonized areas at high altitude or latitude because of the

332 stochasticity of colonization processes (Hamùpe \& Petit 2005; Thompson 2020). However,

333 contrary to this expectation, in L. pomponium we detected the highly genetically diverse

334 populations at high latitude and elevation and the less genetically diverse populations at low

335 altitude or latitude edge. This finding supports the hypothesis of a past range expansion and a

336 recent contraction in relation with the complex phylogeographical history of the Maritime and

337 Ligurian Alps (Médail \& Diadema, 2009). A further analysis aimed precisely at reconstructing

338 past range dynamics would be most interesting here. In contrast to what we have observed in $L$.

339 pomponium, high genetic diversity near the geographical centre has been recorded in other

340 Mediterranean plant species in which a central-marginal pattern may be associated with a history

341 of expansion from a centre of diversity (Pouget et al., 2013). Elsewhere, the pattern we observed 
342 in L. pomponium has been previously detected in 40 species in which environmental distance

343 more closely predicts genetic diversity than geographical distance (Lira-Noriega \& Manthey, 344 2014).

345 The reduction of neutral genetic diversity in environmentally marginal conditions may be 346 due to a cascade effect of environmental impacts on population dynamics (Lira-Noriega \& 347 Manthey, 2014; Pironon et al., 2017). The quality of the local habitat (i.e., distance from the 348 environmental centre) may affect demographic processes (Jaquiéry et al., 2008), ultimately 349 resulting in a reduction in genetic variation due to selection and/or genetic drift. Nevertheless, in 350 L. pomponium some small populations have relatively high genetic diversity (e.g., P03, P14 and 351 P16 in Table 3). The perennial nature of L. pomponium (more than ten years in L. martagon; 352 Lundqvist, 1991) may reduce the effect of genetic drift (Ellstrand \& Elam, 1993; Nybom \& 353 Bartish, 2000). In addition, natural selection may directly play an important role in shaping 354 neutral genetic diversity (Gillespie, 2000; Leffler et al., 2012; Corbett-Detig et al., 2015). In 355 large populations that incur strong environmental filtering, natural selection may directly affect 356 levels of neutral variation and favour variants that are linked to beneficial mutations (Gillespie, 357 2000) and/or purge those linked to deleterious mutations (Kaplan et al., 1989), the so-called 358 genetic draft (Gillespie, 2000). In L. pomponium genetic differentiation may thus be affected by 359 habitat availability that reduces population connectivity while genetic diversity may be affected 360 by habitat quality that affects population dynamics.

361

362

363

364 365

\section{Conclusions}

In conclusion, our study provides support for $\mathrm{CPH}$ predictions of increased differentiation toward the geographical limits of the distribution of this species (Lira-Noriega \& Manthey, 2014; Kennedy et al., 2020). However, we found neither evidence for increased environmental 
366

367

368

369

370

371

372

373

374

375

376

377

378

379

380

381

382

383

384

385

386

387

388

389

390

391

392

393

394

marginality nor a reduction in within-population genetic diversity towards the geographical

periphery. Taken together our results suggest that habitat quality may affect genetic diversity

both by a cascade effect on population dynamics and by purging neutral variation that is linked

to unfavourable mutations. A reduction in available habitat, rather than a decline in

environmental quality, may explain the increase in inter-population genetic differentiation

toward the geographical periphery of the species' range.

\section{Acknowledgements}

The authors thank Katia Diadema and Maëlle Le Berre (Conservatoire botanique national méditerranéen) for their help in populations' sampling.

\section{References}

Arrigo N, Tuszynski JW, Ehrich D, Gerdes T. 2009. Evaluating the impact of scoring parameters on the structure of intra-specific genetic variation using RawGeno, an $\mathrm{R}$ package for automating AFLP scoring. BMC Bioinformatics 10:33 DOI: 10.1186/1471-2105-10-33.

Bonin A, Bellemain E, Eidesen PB, Pompanon F, Brochmann C, Taberlet P. 2004. How to track and assess genotyping errors in population genetics studies. Molecular Ecology 13: 32613273 DOI: 10.1111/j.1365-294X.2004.02346.x.

Brown JH. 1984. On the relationship between abundance and distribution of species. American Naturalist 124: 255-279 DOI:10.1086/284267.

Brown JH, Stevens GC, Kaufman DM. 1996. The geographic range: size, shape, boundaries, and internal structure. Annual Reviews of Ecology and Systematics 27: 597-623 DOI: 10.1146/annurev.ecolsys.27.1.597.

Carlson BZ, Renaud J, Biron PE, Choler P. 2014. Long-term modeling of the forest-grassland ecotone in the French Alps: implications for land management and conservation. Ecological applications 24: 1213-1225 DOI: 10.1890/13-0910.1.

PeerJ reviewing PDF | (2020:05:48726:2:0:NEW 19 Jan 2021) 
395 Casazza G, Grassi F, Zecca G, Minuto L. 2016. Phylogeographic insights into a peripheral

396

397

398

399

400

401

402

403

404

405

406

407

408

409

410

411

412

413

414

415

416

417

418

419

420

421

422

423

424

refugium: The importance of cumulative effect of glaciation on the genetic structure of two endemic plants. PLoS One 11: e0166983 DOI: 10.1371/journal.pone.0166983.

Casazza G, Carta A, Giordani P, Guerrina M, Peruzzi L, Minuto L. 2018. Reproductive biology of the threatened Lilium pomponium (Liliaceae), a species endemic to Maritime and Ligurian Alps. Journal of Plant Research 131: 633-640 DOI: 10.1007/s10265-018-1019-8.

Casazza G, Zappa E, Mariotti MG, Médail F, Minuto L. 2008. Ecological and historical factors affecting distribution pattern and richness of endemic plant species: the case of the Maritime and Ligurian Alps hotspot. Diversity and Distribution 14: 47-58 DOI: 10.1111/j.14724642.2007.00412.x.

Cimmaruta R, Bondanelli P, Nascetti G. 2005. Genetic structure and environmental heterogeneity in the European hake (Merluccius merluccius). Molecular Ecology 14: 2577-2591 DOI: 10.1111/j.1365-294X.2005.02595.x.

Corbett-Detig RB, Hartl DL, Sackton TB. 2015. Natural selection constrains neutral diversity across a wide range of species. PLoS Biology 13: e1002112 DOI: 10.1371/journal.pbio.1002112.

Diadema K, Bretagnolle F, Affre L, Yong-Ming Y, Médail F. 2005. Geographic structure of molecular variation of Gentiana ligustica (Gentianaceae) in the Maritime and Ligurian regional hotspot, inferred from ITS sequences. Taxon 54: 887-894. DOI: 10.2307/25065475

Eckert CG, Samis KE, Lougheed SC. 2008. Genetic variation across species' geographical ranges: the central-marginal hypothesis and beyond. Molecular Ecology 17: 1170-1188 DOI: 10.1111/j.1365-294X.2007.03659.x.

Ellstrand NC, Elam DR. 1993. Population genetic consequences of small population size: Implications for plant conservation. Annual Review of Ecology and Systematics 24: 217-242 DOI: 10.1146/annurev.es.24.110193.001245.

El Mousadik A, Petit RJ. 1996a. Chloroplast DNA phylogeography of the argan tree of Morocco. Molecular Ecology 5: 547-555. DOI: 10.1111/j.1365-294x.1996.tb00346.x.

El Mousadik A, Petit RJ. 1996b. High level of genetic differentiation for allelic richness among populations of the argan tree [Argania spinosa (L.) Skeels] endemic to Morocco. Theoretical and Applied Genetics 92: 832-839. DOI: 10.1007/BF00221895. 
425 Excoffier L, Laval G, Schneider S (2005) Arlequin (version 3.0): an integrated software package

426

427

428

429

430

431

432

433

434

435

436

437

438

439

440

441

442

443

444

445

446

447

448

449

450

451

452

453

454 for population genetics data analysis. Evolutionary bioinformatics online 1:47-50 DOI: $10.1177 / 117693430500100003$

Ennos RA. 1994. Estimating the relative rates of pollen and seed migration among plant populations. Heredity 72: 250-259 DOI: 10.1038/hdy.1994.35.

Excoffier L, Lischer HE. 2010. Arlequin suite ver 3.5: A new series of programs to perform population genetics analyses under Linux and Windows. Molecular Ecology Resources 10: 564-567 DOI: 10.1111/j.1755-0998.2010.02847.x.

Ferreira V, Castro I, Rocha J, Crespí AL, Pinto-Carnide O, Amich F, Almeida R, Carnide V. 2015. Chloroplast and nuclear DNA studies in Iberian Peninsula endemic Silene scabriflora subspecies using cpSSR and ISSR markers: Genetic diversity and phylogenetic relationships. Biochemical Systematics and Ecology 61: 312-318. DOI: 10.1016/j.bse.2015.06.029.

Gaston KJ. 2003. The structure and dynamics of geographic ranges. Oxford University Press, Oxford.

Gavin DG, Fitzpatrick MC, Gugger PF, Heath KD, Rodríguez-Sánchez F, Dobrowski SZ, Hampe A, Hu FS, Ashcroft MB, Bartlein PJ, Blois JL, Carstens BC, Davis EB, de Lafontaine G, Edwards ME, Fernandez M, Henne PD, Herring EM, Holden ZA, Kong W-s, Liu J, Magri D, Matzke NJ, McGlone MS, Saltré F, Stigall AL, Tsai, Y-HE, Williams JW. 2014. Climate refugia: joint inference from fossil records, species distribution models and phylogeography. New Phytologist 204: 37-54 DOI: 10.1111/nph.12929.

Griffin PC, Willi Y. 2014. Evolutionary shifts to self-fertilisation restricted to geographic range margins in North American Arabidopsis lyrata. Ecology Letters 17: 484-490.

Gillespie JH. 2000. Genetic drift in an infinite population: The pseudohitchhiking model. Genetics 155: 909-919.

Hampe A, Petit RJ. 2005. Conserving biodiversity under climate change: the rear edge matters. Ecology Letters 8: 461- 467 DOI: 10.1111/j.1461-0248.2005.00739.x.

Hannah L, Flint L, Syphard AD, Moritz MA, Buckley LB, McCullough IM. 2014. Fine-grain modeling of species' response to climate change: holdouts, stepping-stones, and microrefugia. Trends in Ecology \& Evolution 29: 390-397 DOI: 10.1016/j.tree.2014.04.006. 
455 Harder LD, Barrett SCH. 1995. Mating cost of large floral displays in hermaphrodite plants.

456

457

458

459

460

461

462

463

464

465

466

467

468

469

470

471

472

473

474

475

476

477

478

479

480

481

482

483

484

Nature 373:512-515. https://doi.org/10.1038/373512a0

Hargreaves AL, Eckert CG. 2014. Evolution of dispersal and mating systems along geographic gradients: implications for shifting ranges. Functional Ecology 28: 5-21 DOI: 10.1111/13652435.12170 .

Hengeveld R, Haeck J. 1982. The distribution of abundance. I. Measurements. Journal of Biogeography 9: 303-316 DOI: 10.2307/2844717.

Hewitt GM. 1999. Post-glacial re-colonization of European biota. Biological Journal of the Linnean Society 68: 87-112 DOI: 10.1006/bijl.1999.0332.

Jaquiéry J, Guélat J, Broquet T, Berset-Brändli L, Pellegrini E, Moresi R, Hirzel AH, Perrin N. 2008. Habitat-quality effects on metapopulation dynamics in greater white-toothed shrews, Crocidura russula. Ecology 89: 2777-2785 DOI: 10.1890/07-1833.1.

Jost L. 2008. GST and its relatives do not measure differentiation. Molecular Ecology 17: 40154026 DOI: 10.1111/j.1365-294X.2008.03887.x

Jost L, Archer F, Flanagan S, Gaggiotti O, Hoban S, Latch, E. 2018. Differentiation measures for conservation genetics. Evolutionary Applications 11: 1139-1148. DOI: 10.1111/eva.12590

Kaplan NL, Hudson RR, Langley CH. 1989. The "hitchhiking effect" revisited. Genetics 123: 887899 DOI: $10.1534 /$ genetics.105.050179.

Karger DN, Conrad O, Böhner J, Kawohl T, Kreft H, Soria-Auza RW, Zimmermann NE, Linder HP, Kessler M. 2017a Climatologies at high resolution for the earth's land surface areas. Scientific Data 4: 170122 DOI: 10.1038/sdata.2017.122.

Karger DN, Conrad O, Böhner J, Kawohl T, Kreft H, Soria-Auza RW, Zimmermann NE, Linder HP, Kessler M. 2017b. Data from: Climatologies at high resolution for the earth's land surface areas. Dryad Digital Repository. DOI: 10.5061/dryad.kd1d4

Kennedy JP, Preziosi RF, Rowntree JK, Feller IC. 2020. Is the central-marginal hypothesis a general rule? Evidence from three distributions of an expanding mangrove species, Avicennia germinans (L.) L. Molecular Ecology 29: 704-719 DOI: 10.1111/mec.15365.

Kobayashi N, Horikish T, Katsuyama H, Handa T, Takayanagi K. 1998. A simple and efficient DNA extraction method for plants, especially woody plants. Plant Tissue Culture and Biotechnology 4: 760-780. 
485 Kropf M, Comes HP, Kadereit JW. 2008. Causes of the genetic architecture of south-west

486

487

488

489

490

491

492

493

494

495

496

497

498

499

500

501

502

503

504

505

506

507

508

509

510

511

512

513

European high mountain disjuncts. Plant Ecology \& Diversity 1: 217-228 DOI: $10.1080 / 17550870802331938$.

Körner C. 2003. The use of 'altitude' in ecological research. Trends in Ecology and Evolution. 22: 569-574 DOI: 10.1016/j.tree.2007.09.006.

Leffler EM, Bullaughey K, Matute DR, Meyer WK, Ségurel L, Venkat A, Andolfatto P, Przeworski M. 2012. Revisiting an old riddle: what determines genetic diversity levels within species? PLoS Biology 10: e1001388 DOI: 10.1371/journal.pbio.1001388.

Levin DA, Kerster HW. 1974. Gene flow in seed plants. In: Dobzhansky T, Hecht MK, Steere WC, eds. Evolutionary Biology. Springer, Boston, MA, 139-220 DOI: 10.1007/978-1-46156944-2_5.

Lira-Noriega A. Manthey JD. 2014. Relationship of genetic diversity and niche centrality: a survey and analysis. Evolution 68: 1082-1093 DOI: 10.1111/evo.12343.

Lundqvist A. 1991. Four-locus S-gene control of self-incompatibility made probable in Lilium martagon (Liliaceae). Hereditas, 114: 57-63. doi:10.1111/j.1601-5223.1991.tb00553.x

Macdonald SL, Llewelyn J, Moritz C, Phillips BL. 2017. Peripheral isolates as sources of adaptive diversity under climate change. Frontiers in Ecology and Evolution 5: 88 DOI: 10.3389/fevo.2017.00088.

Macrì C, Dagnino D, Guerrina M, Médail F, Minuto L, Thompson JD, Casazza G. 2021. Effects of environmental heterogeneity on phenotypic variation of the endemic plant Lilium pomponium in the Maritime and Ligurian Alps. Oecologia in press. DOI: 10.1007/s00442020-04806-6

Médail F, Diadema K. 2009. Glacial refugia influence plant diversity patterns in the Mediterranean Basin. Journal of Biogeography 36: 1333-1345. DOI: 10.1111/j.1365-2699.2008.02051.x

Meirmans PG. 2020. Genodive version 3.0: Easy-to-use software for the analysis of genetic data of diploids and polyploids. Molecular Ecology Resources 20: 1126-1131 DOI: 10.1111/1755-0998.13145.

Noble V, Diadema K. 2011. La flore des Alpes-Maritimes et de la Principauté de Monaco. Originalité et diversité. Turriers: Naturalia Publications.

Peer) reviewing PDF | (2020:05:48726:2:0:NEW 19 Jan 2021) 
514 Nunes GT, Mancini PL, Bugoni L. 2017. When Bergmann's rule fails: evidences of environmental 515 selection pressures shaping phenotypic diversification in a widespread seabird. Ecography 516 40: 365-375 DOI: 10.1111/ecog.02209.

517 Nybom H, Bartish IV. 2000. Effects of life history traits and sampling strategies on genetic 518 diversity estimates obtained with RAPD markers in plants. Perspectives in Plant Ecology, 519 520 521 522 523 524 525 526 527 528 529

530

531

532

533

534

535

536

537

538

539

540

541

542

Papuga G, Gauthier P, Pons V, Farris E, Thompson JD. 2018. Ecological niche differentiation in peripheral populations: a comparative analysis of eleven Mediterranean plant species. Ecography 41: 1-15 DOI: 10.1111/ecog.03331.

Parmesan C. 2006. Ecological and evolutionary responses to recent climate change. Annual Review of Ecology, Evolution, and Systematics 37: 637-669. DOI: 10.1146/annurev.ecolsys.37.091305.110100

Patsiou TS, Conti E, Zimmermann NE, Theodoridis S, Randin CF. 2014. Topo-climatic microrefugia explain the persistence of a rare endemic plant in the Alps during the last 21 millennia. Global Change Biology 20: 2286-2300 DOI: 10.1111/gcb.12515.

Pilot M, Jedrzejewski W, Branicki W, Sidorovich VE, Jedrzejewska B, Stachura K, Funk SM. 2006. Ecological factors influence population genetic structure of European grey wolves. Molecular Ecology 15: 4533-4553 DOI: 10.1111/j.1365-294X.2006.03110.x.

Piñeiro R, Aguilar JF, Munt DD, Feliner GN. 2007. Ecology matters: Atlantic-Mediterranean disjunction in the sand-dune shrub Armeria pungens (Plumbaginaceae). Molecular Ecology 16: 2155-2171 DOI: 10.1111/j.1365-294X.2007.03280.x.

Pironon S, Papuga G, Villellas J, Angert A, García MB, Thompson JD. 2017. Geographic variation in genetic and demographic performance: new insights from an old biogeographical paradigm. Biological Reviewers 92: 1877-1909 DOI: 10.1111/brv.12313.

Pironon S, Villellas J, Morris WF, Doak DF, García MB. 2015. Do geographic, climatic or historical ranges differentiate the performance of central versus peripheral populations? Global Ecology and Biogeography 24: 611-620 DOI: 10.1111/geb.12263.

Pouget M, Youssef S, Migliore J, Juin M, Médail F, Baumel A. 2013. Phylogeography sheds light on the central-marginal hypothesis in a Mediterranean narrow endemic plant. Annals of botany 112: 1409-1420 DOI: 10.1093/aob/mct183. 
544 R Core Team (2018) R: A language and environment for statistical computing. R Foundation for 545 Statistical Computing, Vienna, Austria. URL http://www.R-project.org/.

546 Roberts DG, Ottewell KM, Whelan RJ, Ayre DJ. 2014. Is the post-disturbance composition of a 547 plant population determined by selection for outcrossed seedlings or by the composition of

548

549

550

551

552

553

554

555

556

557

558

559

560

561

562

563

564

565

566

567

568

569

570

571

572

573

574

the seedbank? Heredity 112:409-414. https://doi.org/10.1038/hdy.2013.119

Ronfort J, Jenczewski E, Bataillon T, Rousset F. 1998. Analysis of population structure in autotetraploid species. Genetics: 150, 921-930.

Sagarin RD, Gaines SD. 2002. The 'abundant centre' distribution: to what extent is it a biogeographical rule? Ecology Letters 5: 137-147 DOI: 10.1046/j.1461-0248.2002.00297.x.

Sanchez G, Rolland Y, Corsini M, Braucher R, Bourlès D, Arnold M, Aumaître G. 2010. Relationships between tectonics, slope instability and climate change: Cosmic ray exposure dating of active faults, landslides and glacial surfaces in the SW Alps. Geomorphology 117: 1-13 DOI: $10.2503 / \mathrm{jj}$ shs1.81.80.

Schoville SD, Bonin A, François O, Lobreaux S, Melodelima C, Manel S. 2012. Adaptive genetic variation on the landscape: methods and cases. Annual Review of Ecology, Evolution, and Systematics 43: 23-43.

Soulé M. 1973. The epistasis cycle: a theory of marginal populations. Annual Review of Ecology, Evolution and Systematics 4: 165-187 DOI: 10.1146/annurev.es.04.110173.001121.

Tarayre M, Saumitou-Laprade P, Cuguen J, Couvet D, Thompson J. 1997. The spatial genetic structure of cytoplasmic (cpDNA) and nuclear (allozyme) markers within and among populations of the gynodioecious Thymus vulgaris (Labiatae) in southern France. American Journal of Botany 84:1675-1684 DOI: 10.2307/2446465.

Thomas CD, Bodsworth EJ, Wilson RJ, Simmons AD, Davies ZG, Musche M, Conradt L. 2001. Ecological and evolutionary processes at expanding range margins. Nature 411: 577-581 DOI: $10.1038 / 35079066$.

Thomas CD, Cameron A, Green RE, Bakkenes M, Beaumont LJ, Collingham YC, Erasmus BFN, de Siqueira MF, Grainger A, Hannah L, Hughes L, Huntley B, van Jaarsveld AS, Midgley GF, Miles L, Ortega-Huerta MA, Townsend Peterson A, Phillips OL, Williams SE. 2004. Extinction risk from climate change. Nature 427: 145-148 DOI: 10.1038/nature02121.

Thompson JD. 2020. Plant evolution in the Mediterranean. Insights for Conservation. Oxford, UK: Oxford University Press.

Peer) reviewing PDF | (2020:05:48726:2:0:NEW 19 Jan 2021) 
575 Villellas J, Berjano R, Terrab A, García MB. 2014. Divergence between phenotypic and genetic 576 variation within populations of a common herb across Europe. Ecosphere 5: 1-14 DOI: $577 \quad 10.1890 /$ ES13-00291.1.

578 Vidaller C. 2018. Which factors limit the establishment of Brachypodium retusum: a key species 579 in ecological restoration of Mediterranean steppes? D. Phil. Thesis, Agricultural sciences. $580 \quad$ Université d'Avignon.

581 Vos P, Hogers R, Bleeker M, Reijans M, Lee T, van de Hornes M, Zabeau M. 1995. AFLP: a new 582 technique for DNA fingerprinting. Nucleic Acids Research 23: 4407-4414 DOI: $583 \quad 10.1093 / \mathrm{nar} / 23.21 .4407$.

584 Yeh, F.C., Yang, R.C. and Boyle, T. 1999. POPGENE Version 1.32: Microsoft Window-Based 585 Freeware for Population Genetics Analysis. University of Alberta, Edmonton.

586 Young A, Boyle T, Brown T. 1996. The population genetic consequences of habitat fragmentation 587 for plants. Trends in Ecology \& Evolution 11: 413-418 DOI: 10.1016/0169-5347(96)10045$588 \quad 8$.

589 


\section{Table $\mathbf{1}$ (on next page)}

Geographical and environmental distance values for each population

Geographical and environmental distance values for each population: Population code (code), locality name (Loc.), the distance from the distributional centre (dc), the minimum distance from the geographical edge (de), the ratio between edge and centre of distribution (dec), the Euclidean distance from the centroid of the climatic space (eu) and the Mahalanobis distance from the mean of the climatic space (ma) are reported. 
Table 1: Geographical and environmental distance values for each population: Population code (code), locality name (Loc.), the 2 distance from the distributional centre (dc), the minimum distance from the geographical edge (de), the ratio between edge and centre 3 of distribution (dec), the Euclidean distance from the centroid of the climatic space (eu) and the Mahalanobis distance from the mean of 4 the climatic space (ma) are reported.

\begin{tabular}{llrrlll}
\hline code & \multicolumn{1}{c}{ Loc. } & dc $(\mathrm{km})$ & de $(\mathrm{km})$ & \multicolumn{1}{l}{ dce } & \multicolumn{1}{l}{ eu } & \multicolumn{1}{l}{ ma } \\
\hline P01 & Baisse Saint-Paul (FR) & 44.80 & 1.84 & 0.040 & 2.910 & 2.900 \\
P02 & Plateau Tercier (FR) & 35.12 & 2.36 & 0.063 & 2.537 & 2.726 \\
P03 & Fort de la Revère (FR) & 36.13 & 0.64 & 0.017 & 2.809 & 3.704 \\
P04 & Les Pras (FR) & 13.44 & 23.66 & 0.638 & 2.621 & 2.820 \\
P05 & Ciamp du Var (FR) & 9.97 & 24.83 & 0.713 & 2.669 & 2.846 \\
P06 & Tournefort (FR) & 15.14 & 25.11 & 0.624 & 2.473 & 2.198 \\
P07 & Utelle (FR) & 15.90 & 23.14 & 0.593 & 2.325 & 1.718 \\
P08 & Entrevaux (FR) & 15.91 & 25.69 & 0.617 & 1.864 & 2.077 \\
P09 & Gorbio, Col de la Madone (FR) & 36.27 & 5.99 & 0.142 & 2.744 & 5.450 \\
P10 & Col de Vence (FR) & 19.51 & 11.27 & 0.366 & 2.975 & 3.679 \\
P11 & Greolieres (FR) & 14.89 & 17.45 & 0.540 & 1.512 & 0.649 \\
P12 & Mt. Comune (IT) & 47.93 & 12.72 & 0.210 & 0.955 & 0.677 \\
P13 & Mt. Lega (IT) & 51.48 & 15.76 & 0.234 & 0.706 & 0.313 \\
P14 & Castel Tournou (FR) & 55.61 & 0.50 & 0.009 & 1.536 & 0.729 \\
P15 & Méailles (FR) & 34.27 & 9.92 & 0.224 & 1.904 & 1.438 \\
P16 & Peyresq (FR) & 34.23 & 7.99 & 0.189 & 2.397 & 3.502 \\
P17 & Ondres (FR) & 37.66 & 2.69 & 0.067 & 3.627 & 4.140 \\
P18 & Mt. Grai (IT) & 55.24 & 14.98 & 0.213 & 1.977 & 2.527 \\
P19 & L'adrechas (FR) & 25.57 & 8.47 & 0.249 & 2.069 & 1.293 \\
P20 & La Colmiene (FR) & 25.09 & 8.52 & 0.254 & 2.683 & 2.209 \\
\hline
\end{tabular}




\section{Table 2 (on next page)}

Primer pairs used in selective amplifications and summary of the number of AFLP fragments scored 
1 Table 2: Primer pairs used in selective amplifications and summary of the number of AFLP

2 fragments scored

\begin{tabular}{lll}
\hline EcoRI primer & Mselprimer & Number of loci \\
\hline E-AGC & M-CGG & 78 \\
E-AGC & M-CAG & 47 \\
E-AGC & M-CTG & 85 \\
total & & 210 \\
mean & & 70 \\
\hline
\end{tabular}

3

4 


\section{Table 3 (on next page)}

Gene diversity estimates in the total dataset based on AFLP data

Gene diversity estimates in the total dataset based on AFLP data: Population code (code), locality name (Loc.), estimated population size (Size), sample size (N), Nei's diversity index (h), Shannon's information index (I) and, the average of the pair of $F_{S T}$, Jost's $D(D)$ and Rho values between each population and all remaining populations and associated standard deviations (in brackets) are reported. 
Table 3: Gene diversity estimates in the total dataset based on AFLP data: Population code (code), locality name (Loc.), estimated population size (Size), sample size (N), Nei's diversity index (h), Shannon's information index (I) and, the average of the pair of $F_{\text {ST, }}$

3 Jost's D (D) and Rho values between each population and all remaining populations and associated standard deviations (in brackets) are

4 reported.

\begin{tabular}{|c|c|c|c|c|c|c|c|}
\hline code & Loc. & Size & $\mathrm{h}$ & I & $\mathrm{F}_{\mathrm{ST}}$ & $\mathrm{D}$ & Rho \\
\hline P01 & Baisse Saint-Paul (FR) & $\sim 100$ & 0.1141 & 0.1899 & $0.0874(0.0310)$ & $0.0933(0.0750)$ & $0.2004(0.2561)$ \\
\hline P02 & Plateau Tercier (FR) & $\sim 250$ & 0.1930 & 0.3140 & $0.0874(0.0572)$ & $0.0479(0.0544)$ & $0.0119(0.1443)$ \\
\hline $\mathrm{P} 03$ & Fort de la Revère (FR) & $\sim 40$ & 0.2025 & 0.3194 & $0.0344(0.0801)$ & $0.0454(0.0449)$ & $0.1054(0.2352)$ \\
\hline P04 & Les Pras (FR) & $\sim 50$ & 0.2022 & 0.3229 & $0.1408(0.0591)$ & $0.0416(0.0381)$ & $0.0076(0.1621)$ \\
\hline P05 & Ciamp du Var (FR) & $\sim 30$ & 0.1582 & 0.2535 & $0.0551(0.0355)$ & $0.0711(0.0671)$ & $0.0076(0.1621)$ \\
\hline P06 & Tournefort (FR) & $\sim 200$ & 0.2363 & 0.3651 & $0.0711(0.0363)$ & $0.0357(0.0252)$ & $0.0526(0.1059)$ \\
\hline P07 & Utelle (FR) & $\sim 100$ & 0.2489 & 0.3840 & $0.0934(0.0462)$ & $0.0351(0.0200)$ & $0.0076(0.1621)$ \\
\hline P08 & Entrevaux (FR) & $\sim 20$ & 0.2508 & 0.3885 & $0.1132(0.0601)$ & $0.0318(0.0206)$ & $0.0405(0.2031)$ \\
\hline P09 & Gorbio, Col de la Madone (FR) & $\sim 200$ & 0.2102 & 0.3332 & $0.0642(0.0450)$ & $0.0379(0.0446)$ & $0.1054(0.2352)$ \\
\hline P10 & Col de Vence (FR) & $\sim 200$ & 0.2514 & 0.3837 & $0.0691(0.0358)$ & $0.0639(0.0275)$ & $0.1459(0.1406)$ \\
\hline P11 & Greolieres (FR) & $\sim 150$ & 0.2585 & 0.3907 & $0.0615(0.0660)$ & $0.0484(0.0256)$ & $0.0127(0.1968)$ \\
\hline $\mathrm{P} 12$ & Mt. Comune (IT) & $\sim 150$ & 0.2422 & 0.3627 & $0.0942(0.0744)$ & $0.1079(0.0538)$ & $0.0266(0.1239)$ \\
\hline $\mathrm{P} 13$ & Mt. Lega (IT) & $\sim 200$ & 0.2878 & 0.4346 & $0.1161(0.0867)$ & $0.0533(0.0269)$ & $0.3209(0.1862)$ \\
\hline P14 & Castel Tournou (FR) & $\sim 30$ & 0.2466 & 0.3768 & $0.0535(0.0529)$ & $0.0393(0.0196)$ & $0.0098(0.1216)$ \\
\hline P15 & Méailles (FR) & $\sim 250$ & 0.2185 & 0.3380 & $0.0740(0.0574)$ & $0.0392(0.0347)$ & $0.0098(0.1216)$ \\
\hline P16 & Peyresq (FR) & $\sim 70$ & 0.2293 & 0.3452 & $0.0620(0.0520)$ & $0.1054(0.0438)$ & $0.3209(0.1862)$ \\
\hline P17 & Ondres (FR) & $\sim 200$ & 0.1989 & 0.3118 & $0.0896(0.0410)$ & $0.0564(0.0353)$ & $0.3209(0.1862)$ \\
\hline P18 & Mt. Grai (IT) & $\sim 500$ & 0.2738 & 0.4115 & $0.0868(0.0353)$ & $0.0524(0.0251)$ & $0.1054(0.2352)$ \\
\hline P19 & L'adrechas (FR) & $\sim 400$ & 0.2175 & 0.3326 & $0.1524(0.0479)$ & $0.0852(0.0356)$ & $0.0405(0.2031)$ \\
\hline $\mathrm{P} 20$ & La Colmiene (FR) & $\sim 200$ & 0.1758 & 0.2806 & $0.1043(0.0424)$ & $0.0451(0.0428)$ & $0.0394(0.1854)$ \\
\hline
\end{tabular}




\section{Table 4 (on next page)}

Pearson's correlation ( $r$ ) and the significance ( $p$-value) of genetic diversity versus geographical and environmental distances. 
1 Table 4: Pearson's correlation ( $\mathrm{r}$ ) and the significance ( $\mathrm{p}$-value) of genetic diversity versus 2 geographical and environmental distances.

\begin{tabular}{llrrrr}
\hline & & \multicolumn{2}{c}{$\mathrm{h}$} & \multicolumn{2}{c}{ I } \\
& & $\mathrm{r}$ & $\mathrm{p}$-value & \multicolumn{1}{c}{$\mathrm{r}$} & $\mathrm{p}$-value \\
\hline Geographical & Centre distance & 0.319 & 0.171 & 0.116 & 0.624 \\
& Edge distance & 0.142 & 0.551 & 0.328 & 0.158 \\
& Edge/centre distance & 0.169 & 0.476 & 0.182 & 0.441 \\
Environmental & Euclidean distance & -0.761 & $<0.001$ & -0.730 & $<0.001$ \\
& Mahalanobis distance & -0.513 & 0.020 & -0.479 & 0.032 \\
\hline
\end{tabular}

3

4

5 


\section{Table 5 (on next page)}

Pearson's correlation ( $r$ ) and the significance ( $p$-value) of genetic differentiation versus geographical and environmental distances. 
1 Table 5 Pearson's correlation (r) and the significance (p-value) of genetic differentiation versus 2 geographical and environmental distances.

\begin{tabular}{llrrrrrr}
\hline & & \multicolumn{2}{c}{$\mathrm{F}_{\mathrm{ST}}$} & \multicolumn{2}{c}{ Jost's D } & \multicolumn{2}{c}{ Rho } \\
& & $\mathrm{r}$ & $\mathrm{p}$-value & \multicolumn{1}{c}{ r } & p-value & $\mathrm{r}$ & $\mathrm{p}$-value \\
\hline Geographical & Centre distance & -0.115 & 0.630 & 0.248 & 0.292 & 0.397 & 0.083 \\
& Edge distance & 0.276 & 0.238 & -0.242 & 0.305 & -0.324 & 0.164 \\
& Edge/centre distance & 0.207 & 0.381 & -0.255 & 0.277 & -0.407 & 0.075 \\
Environmental & Euclidean distance & 0.015 & 0.949 & -0.064 & 0.787 & -0.011 & 0.964 \\
& Mahalanobis distance & -0.225 & 0.349 & -0.059 & 0.803 & 0.144 & 0.544 \\
\hline
\end{tabular}

3 


\section{Figure 1}

Geographic location of studied populations of Lilium pomponium and the environmental and geographical measures of centrality and, the genetic diversity and differentiation values for each population.

The geographic location of studied populations of Lilium pomponium (A) and the environmental ( $C$ and $E$ ) and geographical ( $B, D$ and $F$ ) measures of centrality and, the genetic diversity $(G)$ and differentiation $(H)$ values for each population. The spatial distribution of distance from the distributional centre (B), the minimum distance from the geographical edge (D) the ratio between edge and centre of distribution (F), the Euclidean distance from the centroid of the climatic space $(C)$ and the Mahalanobis distance from the mean of the climatic space $(E)$ is showed. Circle indicates the geographical centre and triangles indicate populations sampled. Dark red colours represent high distance and light red colours represent low distance.
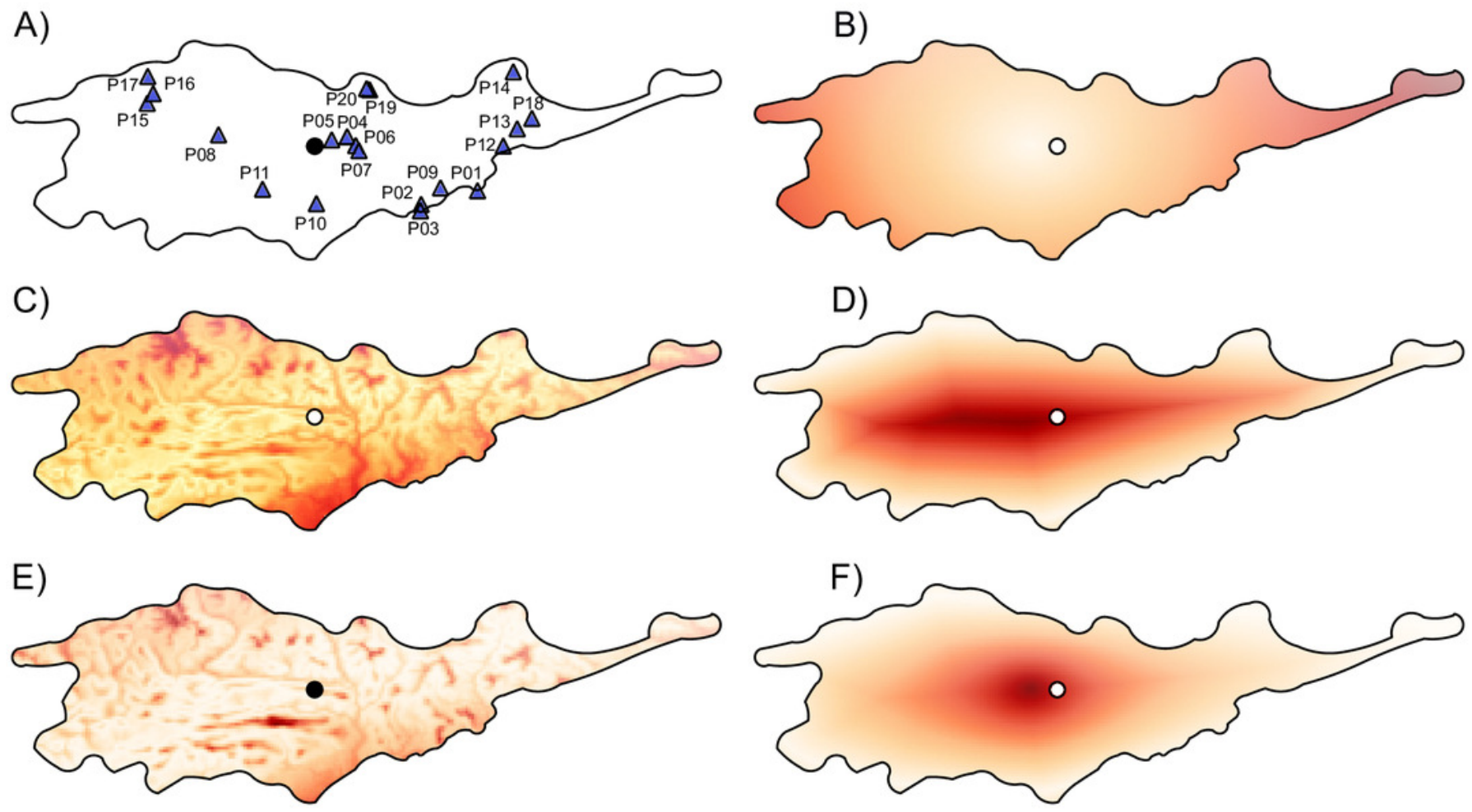


\section{Figure 2}

Linear regressions showing the relationships between measures of environmental marginality and geographic peripherality in Lilium pomponium.

Linear regressions showing the relationships between measures of environmental marginality and geographic peripherality in Lilium pomponium. The relationship between the Euclidean distance from the centroid of the climatic space and distance from the distribution centre (A), the minimum distance from the geographical periphery (B) and the ratio between periphery and centre of distribution (C), and the relationship between the Mahalanobis distance from the mean of the climatic space and the distance from the distributional centre (D), the minimum distance from the geographical periphery $(E)$ and the ratio between the periphery and centre of distribution (F). 

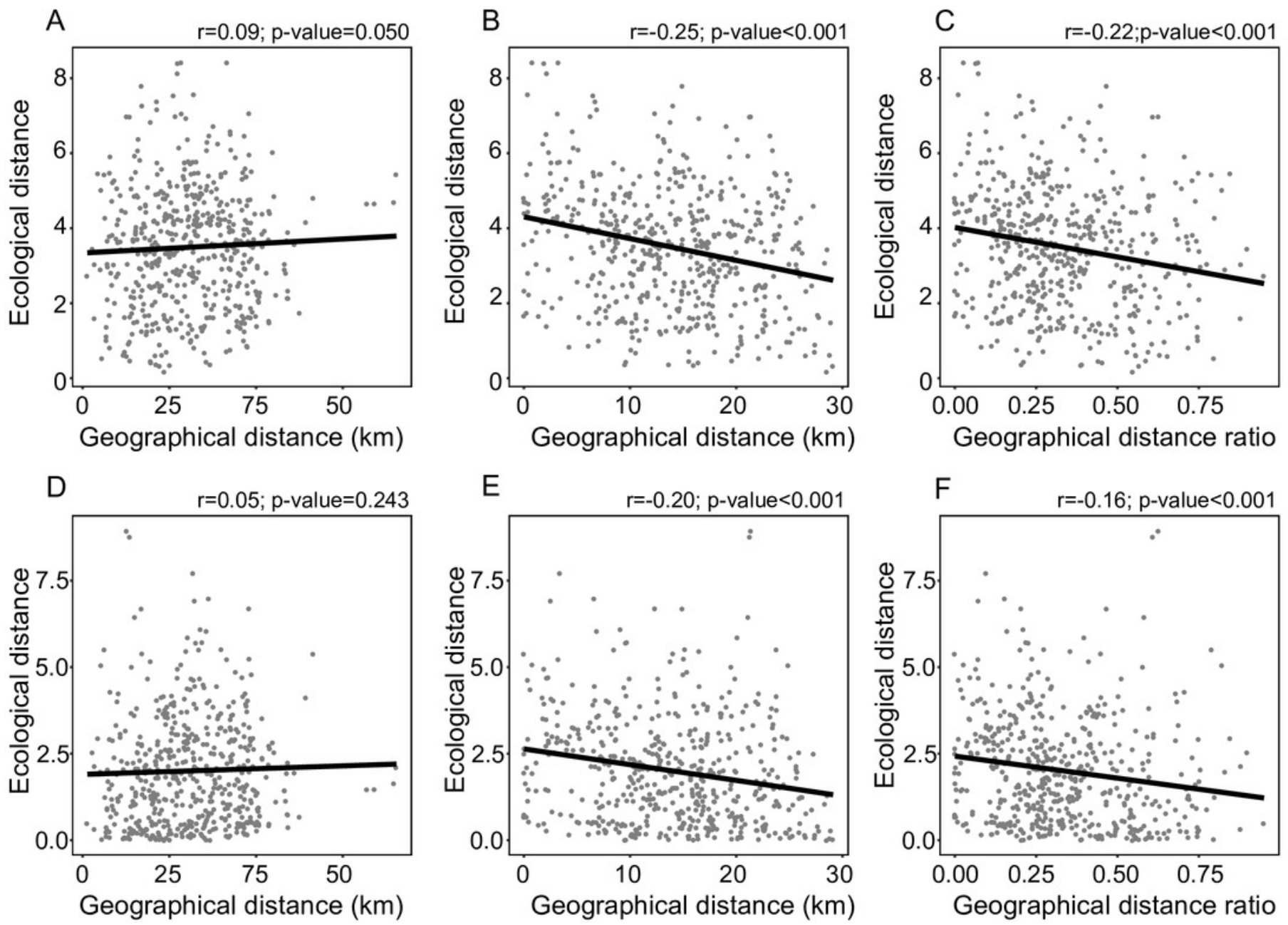
Figure 3

The genetic diversity and differentiation values for each studied populations of Lilium pomponium

The genetic diversity (A-B) and differentiation (C-D) values for each studied populations of Lilium pomponium. Genetic diversity was measured by calculating Nei's diversity index (A) and Shannon's information index (B). Genetic differentiation among populations was estimated by using $F_{S T}(C)$, Jost's $D(D)$ and Rho (E). Circle indicates the geographical centre and triangles indicate populations sampled. Dark red colours represent high value and light red colours represent low value. Pearson's product moment correlations and significance values are reported above each plot.
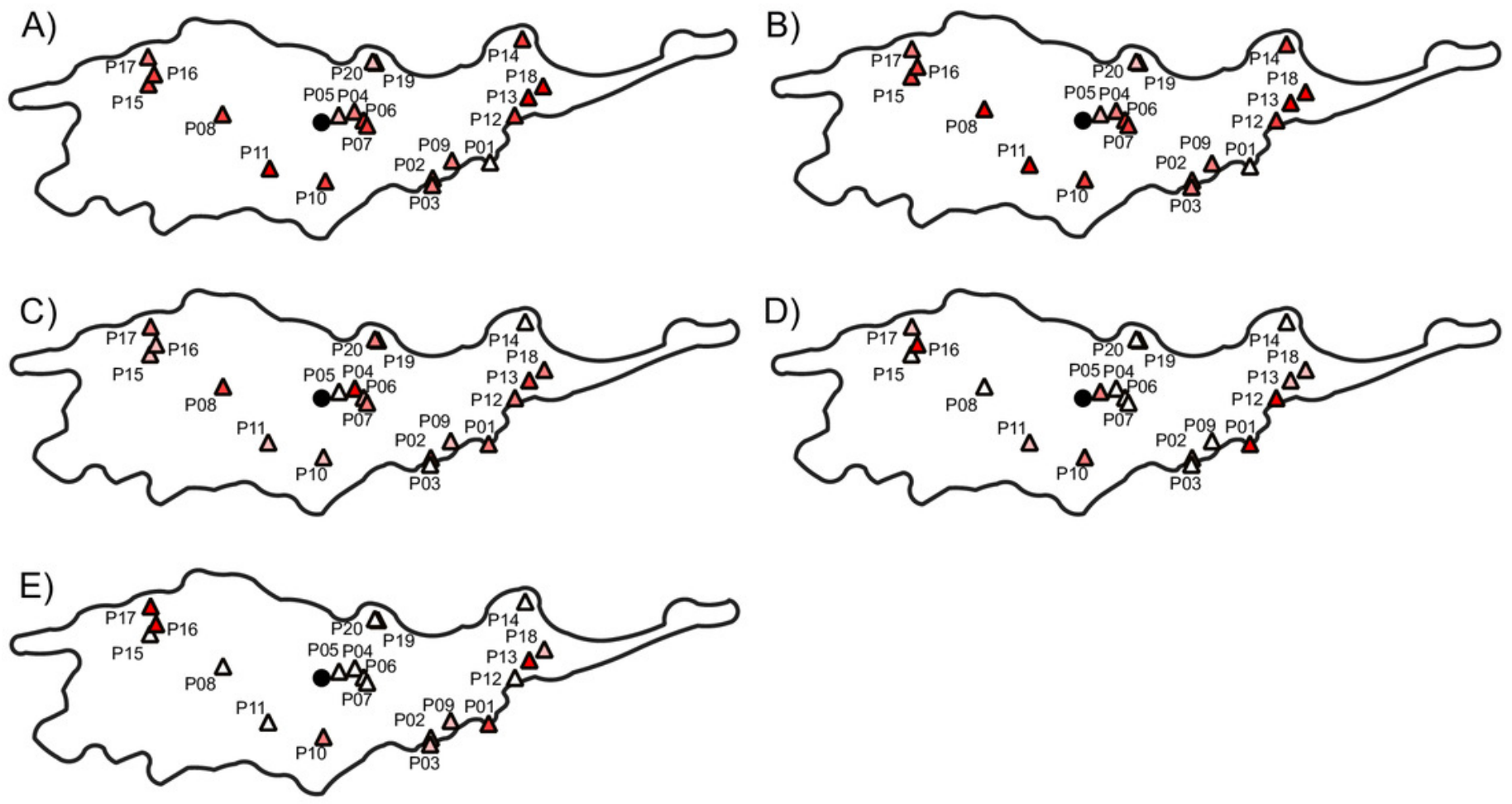